\section{Formation of Catalyst Model Dispersed of Pd on a thin MgO (100)} Department of Physics, Faculty of Sciences,Badji Mokhtar University-Annaba-Algeria. - baarafatma@yahoo.fr Prof. Abdelbakı CHEMAM - Preparatory School for Science and Technology of Annaba,

Érkezett: 2014. 10. 10. - Received: 10. 10. 2014. " http://dx.doi.org/10.14382/epitoanyag-jsbcm.2014.18

\begin{abstract}
The nucleation kinetics or the formation of a catalyst model dispersed for the system $\mathrm{Pd} /$ thin MgO (100) are calculated by developing many programs using Fortran software. This simulation is based upon parameters studied in situ by transmission electron microscopy (TEM), related to the first quantitative study on the nucleation and the growth. Palladium nanoparticles deposited on thin $\mathrm{MgO}$ are tested in the temperature range 573-1073 $\mathrm{K}$ and deposition time of $1000 \mathrm{~s}$. The nucleation kinetics are interpreted according to the theory of random nucleation. The general scheme is consisting of three stages namely, nucleation, growth and coalescence. The saturation density of clusters decreases when the substrate temperature increases following Arrhenius law. This behavior is in agreement with a recent AFM study for $\mathrm{Ag} / \mathrm{MgO}$ and $\mathrm{Au} / \mathrm{MgO}$. The phenomenon of coalescence is explained via island migration process. It is shown that the coalescence occurs more rapidly when the substrate temperature is high.

Keywords: catalists, crystals, magnesium-oxide, nucleation kinetics, palladium
\end{abstract}

DR. FAtmA BAARA - Laboratory of surfaces and interfaces of solids studies - (LESIMS) Annaba 23000, Algeria. - a.chemam@epst-annaba.dz

Baara Fatma

is a lecturer at the Department of Physics in the Badji Mokhtar University Annaba and has wide range experiments in investigation of surface properties of solids. Dr. Baara is author of several scientific papers in which the interface properies and behaviors of solids are descripted.

Abdelbaki Chemam
is an expert of applied physics and has a wide
range experiments in scanning tunneling
microscopy. He is author of several scientific
papers in field of condensed matter physics and
theory. Prof. Cheman is a regular participant
of ic-cmtp conferences in Lillafüred (Hungary)
and at present his Research Gate ranking has
achived the 6.06 value.

\section{Introduction}

Nowadays, nano-objects provide a promising research for the identification of new fundamental properties of the materials and their potential technological applications. Much effort is devoted to understand the physical and chemical properties of materials, which can serve as model catalyst systems. Consequently, fundamental studies have been carried out on a range of heterogeneous catalyst, for example, metal islands grown on thin films [1-11] or on single-crystals surfaces [1218]. Palladium deposits on the $\mathrm{MgO}(100)$ surface have become one of the most widely used model systems, and have given rise to many detailed experimental studies [19-21]. Although the main microscopic steps governing nucleation and growth of the films are now understood, detailed characterization of these processes has proven difficult. Earlier, empirical and theoretical studies of Pd over single crystals $\mathrm{MgO}$, investigated defect nucleation [22-28] when nucleation centres occupy minority of sites. On the other hand, the results of nucleation kinetics over thin films governed by random nucleation $[1,29]$, each atomic site is potentially a nucleation centre. In this study, we build upon many experimental and theoretical studies [1, 30-32] have been carried out to understand these processes. The aim of this work is to investigate the microscopic mechanisms, which can calculate various parameters related to the quantitative study focusing on the nucleation, growth and coalescence of $\mathrm{Pd} /$ thin $\mathrm{MgO}$ (100) using Fortran software.

\subsection{Transmission electron microscopy experiments}

To understand the first quantitative study of nucleation and growth of $\mathrm{Pd}$ on thin layer of $\mathrm{MgO}(100)$,we exploited the experimental work of Henry et al [1],who used transmission electron microscopy and electron diffraction at high energy to measure the Pd island density as a function of time a given temperature and a constant flux. Firstly, the MgO (100) / LiF
(100) / $\mathrm{NaCl}$ (100) composite layer is achieved which serves as support. Palladium is then deposited with a flux of $1 \times 10^{13}$ atoms $\mathrm{cm}^{-2} \times \mathrm{s}^{-1}$ and exposure time of 10 to $240 \mathrm{~s}$ on a substrate heated at temperatures between 573 and 673K. After deposition, the Pd islands are in situ characterized with a transmission electron microscopy (TEM) to determine the island density. The results are interpreted according to the theory of random nucleation. The energy of adsorption and diffusion of palladium on $\mathrm{MgO}$ (100) are derived from the latter theory. It was possible to vary the average size of particles in the range $0.8-3.5 \mathrm{~nm}$. The obtained cluster density varies from 0.6 to $3 \times 10^{12} \mathrm{~cm}^{-2}$ however the covered area of the substrate surface is of 0.4 to 15 percent.

\subsection{Over view of nucleation and growth theories}

Nucleation on a surface has been discussed in both classical thermodynamic and in atomistic terms, and both have a long history. Classical nucleation theory was developed by Volmer [33]. From this theory, the critical nucleus is only one atom, which means that the dimer is already stable. In that case, the classical nucleation theory is no longer applicable. The growth process occurs by accretion of adatoms. It is described by the atomistic nucleation theory, which has been developed by Zinsmeister [32]. In this case, the critical nucleus composites of two atoms and the supercritical nuclei do not dissociate. The probability of adsorption is equal to one and that only single atom can return in the phase steam. The frequency of nucleation is then determined by the frequency of meeting of adsorbed atoms.

\subsubsection{Nucleation kinetics}

The rate equations given by Zinsmeister express the variation with time of the number of clusters of size i: $\frac{d n_{i}}{d t}=\omega_{i-1} n_{i-1}-\omega_{i} n_{i}$ for $\mathrm{i}=2,3 \ldots \infty$ 
$\omega_{i}$ is the attachment frequency of an adatom to a cluster containing i atoms which is expressed by:

$$
\omega_{i}=\sigma_{i} D n_{i}
$$

where $\sigma_{i}$ is the capture number for a cluster of size $i$. We have to integrate the system of differential equations in order to calculate the number of nuclei present on the substrate. For sake of simplicity Zinsmeister assumes that it is a constant between 1 and 4. From this scheme the nucleation frequency is:

$J=2 \omega_{1} n_{1}$

Supposing that the growth is negligible, the density of adatoms is equal to the stationary value:

$n_{1}=\mathrm{F} \tau$

where $\mathrm{F}$ is the flux of atoms impinging on the substrate and $\tau$ the mean life time of an adatom before desorption. Then, combining equations (2) and (4) the nucleation rate becomes:

\section{$J=2 \sigma_{1} D F^{2} \tau^{2}$}

The nucleation rate is proportional to the square of the impinging flux for a homogeneous substrate without defects.

\subsubsection{Growth kinetics.}

Zinsmeister has solved the system of differential equation assuming a constant value for the attachment frequency $\left(\omega_{\mathrm{i}}\right)$ [18]. However by this treatment several characteristics of the growth of clusters are not taken into explanation. Several researches have tried to treat more precisely the calculation of the attachment frequencies [34-39]. In the typical growth, the diffusion of adatoms is limited by desorption and the diffusion length $\mathrm{X}_{\mathrm{s}}$ of an adatom is:

$X_{s}=(D \tau)^{1 / 2}$

where $\mathrm{D}_{s}$ is the surface diffusion coefficient. It is expressed by:

$D_{s}=\left(a_{0}^{2} v_{d}\right) \exp \left(-\frac{E_{d}}{K T_{s}}\right)$

Then the mean life time of a physisorbed molecule can be explained by:

$\tau=\left(1 / v_{a}\right) \exp \left(\frac{E_{a}}{K T_{s}}\right)$

where $E_{a}$ and $E_{d}$ is the adsorption and the diffusion energy, and $\mathrm{a}_{0}$ the jump distance, of the order of the surface repeat distance, say 0.2-0.5 $\mathrm{nm}[40], v_{\mathrm{d}}$ and $v_{\mathrm{a}}$ the frequency factors for the diffusion and the adsorption process, $\mathrm{K}$ the Boltzmann constant and $\mathrm{T}_{\mathrm{s}}$ the substrate temperature. In a general case, the growth rate of a cluster can be expressed by a power law of the deposition time.

\section{$R(t)=R_{0} t^{p}$}

The exponent for any experimental has been calculated in the case of the lattice approximation for $3 \mathrm{D}$ clusters.

\subsubsection{Coalescence}

The transformation of two touching nuclei into one nucleus can be described by a time constant shown by Nichols and Mullins [41]:
$\tau_{c}=0.2\left(\frac{R^{4}}{B}\right) \quad$ with $B=\frac{\gamma \Omega^{4 / 3} D_{s}}{K T_{s}}$

where $\mathrm{R}$ is the radius of the coalescing spheres, $\gamma$ the surface free energy and $\Omega$ the atomic volume of $\mathrm{Pd}$.

\subsubsection{Algorithm}

We have been developed many programs exploiting Fortran software. The following list details this mapping.

1. Pd deposition flux rate on $\mathrm{MgO}(100)$ is $1.13 \times 10^{13}$ atoms $\mathrm{cm}^{-2} \times \mathrm{s}^{-}{ }^{1}$.

2. Pd atoms are deposited randomly onto the surface with activation energy of about $0.22 \mathrm{eV}$.

3. $\mathrm{Pd}$ nanoparticles deposited on thin $\mathrm{MgO}$ are tested in the temperature range $573-1073 \mathrm{~K}$ and deposition time of $1000 \mathrm{~s}$.

4. Pd islands are approximated to be three-dimensional clusters.

5. The diffusion of adatoms is limited by desorption. Hence, the values of the surface diffusion are calculated by combination of Equations (6) and (7).

6. The entry parameters are: the velocity of nucleation, velocity of growth, the average mean life time, the surface repeat distance, the diffusion length, the surface free energy, the atomic volume of $\mathrm{Pd}$, the activation and the diffusion energies.

\section{Results}

Fig. 1 shows the variation of cluster density as a function of exposure time at different substrate temperatures ranging from $573 \mathrm{~K}$ to $1073 \mathrm{~K}$ and a constant palladium flux $1 \times 10^{13}$ atoms $\mathrm{cm}^{-2} \times \mathrm{s}^{-1}$. For Ts $=573 \mathrm{~K}$ and $673 \mathrm{~K}$, we can see that the density of clusters is increasing rapidly after 10 to $70 \mathrm{~s}$ (see table 1) due to the large adsorption energy for the Pd adatom confirming the nucleation stage, up to a plateau (saturation density) corresponding to $\mathrm{n}_{\mathrm{s}}=3 \times 10^{12} \mathrm{~cm}^{-2}$ and $1.6 \times 10^{12} \mathrm{~cm}^{-2}$ respectively. A similar behavior is observed for the remaining substrate temperatures till the coalescence occurrence, were the cluster density decreases. It is worth to note that the cluster density decreases when the temperature increases.

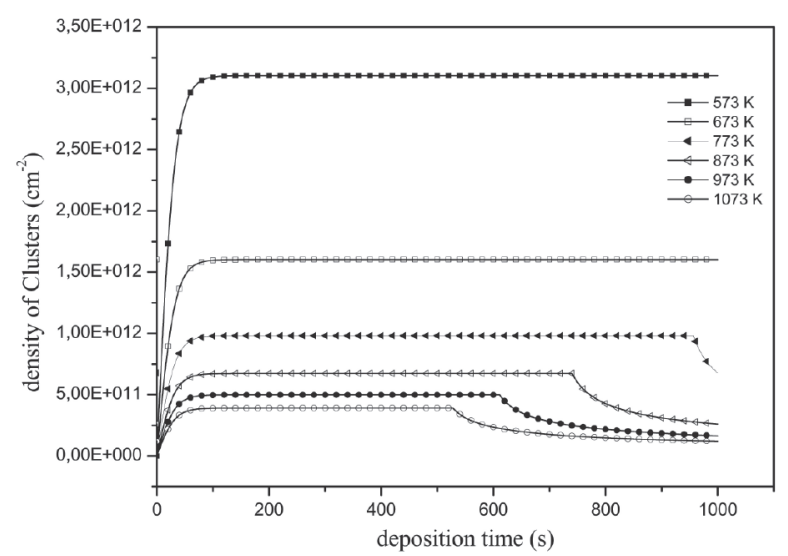

Fig. 1. Nucleation kinetics of $P d$ on $\mathrm{MgO}(100)$ at different substrate temperatures for a palladium flux $1 \times 10^{13}$ atoms $\mathrm{cm}^{-2} \times \mathrm{s}^{-1}$.

1. ábra A Pd nukleáció kinetikája $\mathrm{MgO}$ (100) vékony rétegen különbözö szubsztrátum hömérsékleten, ha a palládium fluxus nagysága $1 \times 10^{13}$ atom $/ \mathrm{cm}^{2}$ s. 


\begin{tabular}{|c|c|c|c|c|c|c|}
\hline$t(s)$ & $573 \mathrm{~K}$ & $673 \mathrm{~K}$ & $773 \mathrm{~K}$ & $873 \mathrm{~K}$ & $973 \mathrm{~K}$ & $1073 \mathrm{~K}$ \\
\hline 10 & 9.39E11 & $4.85 \mathrm{E} 11$ & 2.97E11 & 2.03E11 & 1.50E11 & $1.18 \mathrm{E} 11$ \\
\hline 70 & 3.02E12 & 1.56E12 & $9.58 \mathrm{E} 11$ & 6.56E11 & 4.86E11 & 3.81E11 \\
\hline$\tau_{c}$ & No & No & 9.80E11 & $6.71 \mathrm{E} 11$ & 4.98E11 & 3.90E11 \\
\hline 1000 & 3.02E12 & 1.60E12 & 6.77E11 & 2.59E11 & 1.64E11 & 1.19E11 \\
\hline \multicolumn{7}{|c|}{$\begin{array}{l}\text { Table 1. Calculated of the cluster density }\left(\mathrm{cm}^{-2}\right) \text { at different substrate temperatures (I } \\
\text { and deposition times }(s) \text {. }\end{array}$} \\
\hline \multicolumn{7}{|c|}{$\begin{array}{l}\text { 1. táblázat A különbözö K hömérsékletekre és „lerakódási” idökre (sec) számitott } \\
\text { klaszter-sürüségek }\left(\mathrm{cm}^{2}\right) \text {. }\end{array}$} \\
\hline
\end{tabular}

In Fig. 2, the saturation density is plotted in an Arrhenius diagram. It is represented by the equation: $\mathrm{n}_{\mathrm{s}}=\mathrm{B}_{0} \times \exp (\mathrm{E} /$ $\mathrm{K} \times \mathrm{T}_{\mathrm{s}}$ ). When the activation energy $\mathrm{E}$ is equal to $0.22 \pm 0.05$ $\mathrm{eV}, \mathrm{B}_{0}$ (pre exponential factor) is $3.63 \times 10^{10} \mathrm{~cm}^{-2}$. We show that it increases when the substrate temperature decreases. This behavior is in agreement with a recent AFM study for $\mathrm{Ag} / \mathrm{MgO}$ [42], $\mathrm{Au} / \mathrm{MgO}(100)$ [43] and our previous studies by TEM [1] on the same system.

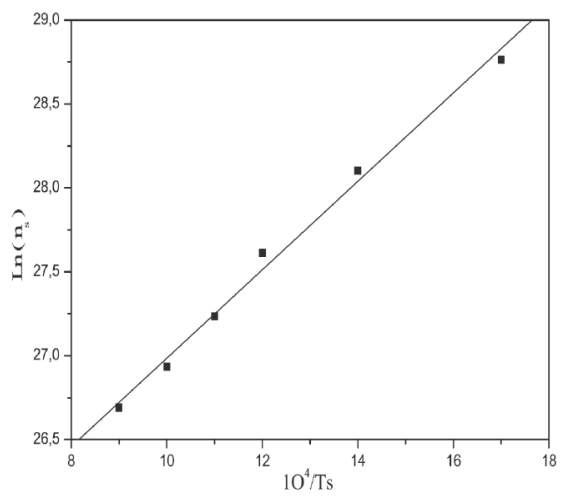

Fig. 2. Arrhenius plot of the saturation density of palladium clusters on $\mathrm{MgO}$ (100).

2. ábra A palládium klaszerek Arrhenius féle telítettségi sürüsége az $\mathrm{MgO}(100)$ vékony rétegen.

Fig. 3 and 4 show the variations of the covered area (A) and the coalescence parameter (B) as a function of substrate temperatures obtained under the same conditions. We see that the fraction of covered area decreases when deposition temperature rises. An opposite behavior is observed for the coalescence parameter.

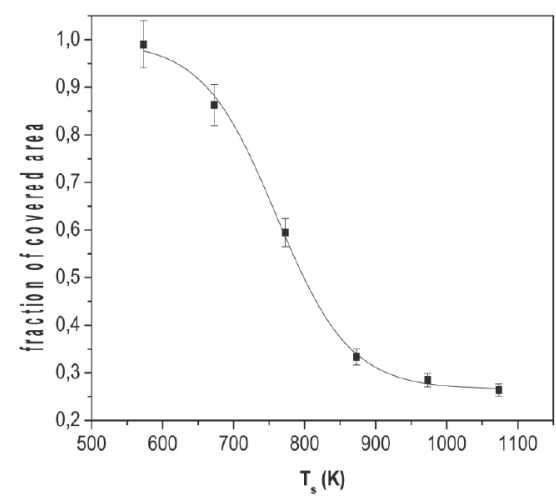

Fig. 3. Variation of the covered area (A) as a function of substrate temperatures with deposition times 1000s.

3. ábra Az 1000 másodperc idő alatt lerakódott felület (A) nagyságának változása a szubsztrátum hőmérséklet függvényében

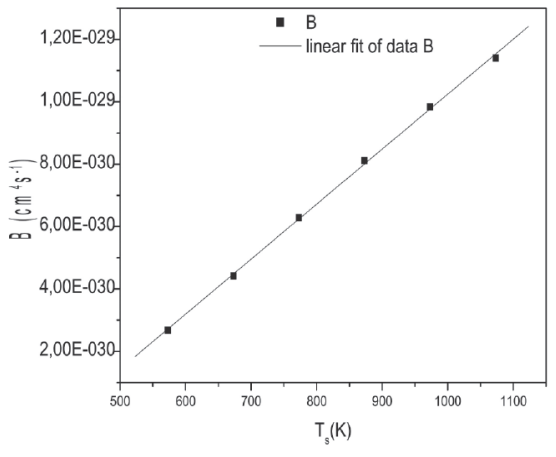

Fig. 4. Variation of the coalescence parameter (B) as a function of substrate temperatures with deposition times 1000 s.

4. ábra Az $1000 \mathrm{sec}$. idő alatt létrejött egyesülések száma (B) a szubsztrátum hömérséklet függvényében.

\section{Discussion}

From our previous empirical result for $\mathrm{Pd} / \mathrm{MgO}$ thin film, the initial nucleation curves suggest the occurrence of a random nucleation mechanism. The theory of this nucleation process is expressed by the kinetic equations of Zinsmeister [32]. Robinson and Robins [30] have given analytical solutions in two limit cases, namely at low and high temperature. In this work, we focus on the high substrate temperatures(regime of incomplete condensation), where the particle number density is given by:

$$
n=n_{s} \tanh (t / \tau)
$$

when the random nucleation model is used, the calculated curves in the first stage agree well with the experimentally measured [1] time dependencies of island density (see nucleation regime in Fig. 1). Hence, the curves show a plateau as a maximum particle density reached at the end of the nucleation regime characterizing the Volmer Weber growth. The value of saturation of the island density is an important parameter which determine the mode of thin film growth. The latter has an evident influence on the physicochemical properties of the obtained thin films [28]. The linear behavior of the Arrhenius plot observed for the temperature dependence of the saturation density of clusters has been also found in the case of $\mathrm{Ag} / \mathrm{Ar}$-cleaved $\mathrm{MgO}\left(\begin{array}{lll}1 & 0 & 0\end{array}\right)$ [42], $\mathrm{Au} / \mathrm{MgO}\left(\begin{array}{lll}1 & 0 & 0\end{array}\right)$ [43] and $\mathrm{Pd} / \mathrm{UHV}$-cleaved $\mathrm{MgO}\left(\begin{array}{lll}1 & 0 & 0\end{array}\right)[44,45]$.

$$
n=n_{s}(1+t / \tau)^{-3 / m} \text {, with } \mathrm{m}=7
$$

The coalescence curves were better fitted with a Cluster diffusion model [31] rather than Ostwald ripening model.

The most crucial parameter in our results is the coalescence time. It is defined as the mean time for two clusters that come into contact to coalesce. From Eq. (10), we can note that two parameters are important to determine the duration of the coalescence stage, which are $\mathrm{R}$ and $\mathrm{B}$. One can also notice the influence of the deposition temperature, that modifies the clusters coalescence time. It is clearly seen that clusters coalesce more rapidly at high temperature [46]. This phenomenon is explained by the process of island migration.

The process of island migration in this calculation is essentially described by the parameter B. The derived B values from Fig. 4 are not high enough meaning that the process of island density coalescence is not ignored even at the initial stages of deposition [47]. The mechanism of coalescence which can be expected at 
such a low value of surface coverage is the migration of islands on the surface, prior to the mechanism of immobile islands in which the coalescence occurs at high values of surface coverage when the islands touch each other [48].

The surface coverage does not depend on B parameter, but it strongly depends on the cluster density and the shape of the particles. The fraction of the substrate covered by the clusters, which is considered as the contact surface of the half sphere is a circle can be written as:

$$
A=\frac{\pi}{4} n D^{2}
$$

In this range of temperatures, the diameter (D) of the clusters follows a power law: $\mathrm{D}_{\mathrm{o}} \mathrm{t}^{\mathrm{p}}$ with $0.33<\mathrm{P}<0.55$. At $573 \mathrm{~K}$ and $673 \mathrm{~K}$, our previous experimental work yielded values of $\mathrm{D}_{\mathrm{o}}$; P equals $0.024 \mathrm{~nm}, 0.8$ and $0.372 \mathrm{~nm}, 0.39$ respectively [1]. The obtained values are used for the calculated curves of the covered area of the substrate surface.

As indicated in the last section the cluster density decreases when the substrate temperature increases due to the increased ad-atom mobility [34]. In addition, we assumed that $D$ is relatively constant with a low error $(\Delta \mathrm{D} / \mathrm{D}=11 \%)$. Accordingly, the fraction of the substrate covered by the particles decreases and the decrease is more pronounced when the coalescence occurs. This behavior is in good agreement with growth rate of the particles in the case of the random nucleation theory [49].

\section{Conclusions}

In the present study, we have simulated the microscopic mechanisms, which can calculate various parameters related to the formation of Pd / thin MgO (100) using FORTRAN software. The formation kinetics follows a general scheme consisting of three stages: nucleation, growth and coalescence. It is determined that saturation density obeys an Arrhenius law with activation energy of $0.22 \mathrm{eV}$ as a fit parameter. It is observed that the variation of island density upon time reaches the saturation. In some cases the cluster density decreases slowly after a saturation regime. The latter decrease is interpreted via the processes of islands migration .It is shown that the coalescence time and the fraction of the substrate covered by the clusters decrease when the temperature increases. Furthermore, the clusters coalesce more rapidly when the temperature increases.

\section{Acknowledgment}

This paper is made on the basis of poster presentation of ic-cmtp3 conference, which was held in Lillafüred, Miskolc (Hungary) in October 6-10, 2014 of which print permission is gratefully acknowledged. The help of R. Chemam, A. Amara and M.Ghers is gratefully acknowledged.

\section{References}

[1] Chapon, C. - Henry, C. R. - Chemam, A.: (1985) Formation and characterization of small $\mathrm{Pd}$ particles deposited on $\mathrm{MgO}$ as a model catalyst, Surface Science, Vol. 162, No. 1-3, 1985, pp. 747-754 http://dx.doi.org/10.1016/0039-6028(85)90975-6

[2] Stiehler, Christian - Pan, Yi - Schneider, Wolf-Dieter - Koskinen, Pekka - Häkkinen, Hannu - Nilius, Niklas - Freund, Hans-Joachim: (2013) Electron quantization in arbitrarily shaped gold islands on $\mathrm{MgO}$ thin films, Physical Review B, Vol. 88, 2013, 115415 http://dx.doi.org/10.1103/PhysRevB.88.115415
[3] Shao, Xiang - Cui, Yi - Schneider, Wolf-Dieter - Nilius, Niklas - Freund, Hans-Joachim: (2012) Growth of Two-Dimensional Lithium Islands on $\mathrm{CaO}(001)$ Thin Films, The Journal of Physical Chemistry C, Vol. 116, No. 33, 2012, pp. 17980-17984

http://dx.doi.org/10.1021/jp306328c

[4] Wang, Hui-Feng - Ariga, Hiroko - Dowler, Rhys - Sterrer, Martin Freund, Hans-Joachim: (2012) Surface science approach to catalyst preparation - Pd deposition onto thin $\mathrm{Fe}_{3} \mathrm{O}_{4}\left(\begin{array}{lll}1 & 1 & 1\end{array}\right)$ films from $\mathrm{PdCl}_{2}$ precursor, Journal of Catalysis, Vol. 286, 2012, pp. 1-5 http://dx.doi.org/10.1016/j.jcat.2011.09.026

[5] Freund, Hans-Joachim - Heyde, Markus - Nilius, Niklas - Schauermann, Swetlana - Shaikhutdinov, Shamil - Sterrer, Martin: (2013) Model studies on heterogeneous catalysts at the atomic scale: From supported metal particles to two-dimensional zeolites, Journal of Catalysis, Vol. 308, 2013, pp. 154-167 http://dx.doi.org/10.1016/j.jcat.2013.06.007

[6] Hansen, K. H. - Worren, T. - Stempel, S. - Lægsgaard, E. - Bäumer, M. - Freund, H. J. - Besenbacher, F. - Stensgaard, I.: (1999) Palladium Nanocrystals on $\mathrm{Al}_{2} \mathrm{O}_{3}$ : Structure and Adhesion Energy, Physical Review Letters, Vol. 83, No. 20, 1999, pp. 4120-4123

http://dx.doi.org/10.1103/PhysRevLett.83.4120

[7] Yang, B. - Emmez, E. - Kaden, W. E. - Yu, X. - Boscoboinik, J. A. - Sterrer, M. - Shaikhutdinov, S. - Freund C.,H.-J. : (2013) Hydroxylation of MetalSupported Sheet-Like Silica Films, The Journal of Physical Chemistry C, Vol. 117, No. 16, 2012, pp. 8336-8344 http://dx.doi.org/10.1021/jp401935u

[8] Ringleb, Franziska - Sterrer, Martin - Freund, Hans-Joachim: (2013) Preparation of $\mathrm{Pd}-\mathrm{MgO}$ model catalysts by deposition of $\mathrm{Pd}$ from aqueous precursor solutions onto $\operatorname{Ag}\left(\begin{array}{lll}0 & 0 & 1\end{array}\right)$-supported $\mathrm{MgO}\left(\begin{array}{lll}0 & 0 & 1\end{array}\right)$ thin films, Applied Catalysis, Vol. 474, 2014, pp. 186-193 http://dx.doi.org/10.1016/j.apcata.2013.05.031

[9] Meyer, R. - Baumer, M. - Shaikhutdinov, Sh. K. - Freund, H.-J. : (2003) Twodimensional growth of $\mathrm{Pd}$ on a thin $\mathrm{FeO}\left(\begin{array}{lll}1 & 1 & 1\end{array}\right)$ film: a physical manifestation of strong metal-support interaction, Surface Science, Vol. 546, No. 2-3, 2003, pp. L813-L819 http://dx.doi.org/10.1016/j.susc.2003.09.025

[10] Giorgi, J.B. - Schroeder, T. - Baumer, M. - Freund, H.-J.: (2002) Study of $\mathrm{CO}$ adsorption on crystalline-silica-supported palladium particles, Surface Science, Vol. 498, No. 1-2, 2002, pp. L71-L77 http://dx.doi. org/10.1016/S0039-6028(01)01756-3

[11] K. Wolter, - H. Kuhlenbeck, - H.-J. Freund,: (2002) Hydrodynamic Voltammetry at the Liquid/Liquid Interface: The Rotating Diffusion Cell, The Journal of Physical Chemistry C, Vol. 106, No. 26, 2002, pp. 67236739 http://dx.doi.org/10.1021/jp025683e

[12] P. Nolte, - A. Stierle, - N. Kasper, - N.Y. Jin-Phillipp, - N. Jeutter, H. Dosch,: (2011) Reversible Shape Changes of Pd Nanoparticles on MgO(100), Nano Letters, Vol. 11, No. 11, pp. 4697-4700 http://dx.doi.org/10.1021/nl2023564

[13] Nolte, P. - Stierle, A. - Kasper, N. - Jin-Phillipp, N. Y. - Reichert, H. Rühm, A. - Okasinski, J. - Dosch, H. - Schöder, S.: (2008) Combinatorial high-energy $\mathrm{x}$-ray microbeam study of the size-dependent oxidation of $\mathrm{Pd}$ nanoparticles on MgO(100), Physical Review B, Vol. 77, 2008, 115444 http://dx.doi.org/10.1103/PhysRevB.77.115444

[14] Jak, M. J. J. - Konstapel, C. - Van Kreuningen, A. - Verho-even, J. - Frenken, J. W. M.: (2000) Scanning tunnelling microscopy study of the growth of small palladium particles on $\mathrm{TiO}_{2}(110)$, Surface Science, Vol. 457, No. 3, 2003, pp. 295-310 http://dx.doi.org/10.1016/S0039-6028(00)00431-3

[15] Pang, C. L. - Raza, H. - Haycock, S. A. - Thornton, G. : (2000) Growth of copper and palladium on $\alpha-\mathrm{Al}_{2} \mathrm{O}_{3}(0001)$, Surface Science, Vol. 460, No. 1-3, 2000, pp. L510-514. http://dx.doi.org/10.1016/S0039-6028(00)00594-X

[16] Stone, P. - Bennett, R. A. - Poulston, S. - Bowker, M. : (1999) Scanning tunnelling microscopy and Auger electron spectroscopy study of Pd on TiO2(110), Surface Science, Vol. 433-435, 1999, pp. 501-505 http://dx.doi.org/10.1016/S0039-6028(99)00485-9

[17] Xu, C. - Lai, X. - Zajac, G. W. - Goodman, D. W. : (1997) Scanning tunneling microscopy studies of the TiO2(110) surface: Structure and the nucleation growth of Pd, Physical Review B, Vol. 56, 1997, 13464 http://dx.doi.org/10.1103/PhysRevB.56.13464

[18] Henry, C. R. - Poppa, H.: (1988) Effect of substrate preparation on the structure and chemisorption properties of $\mathrm{Pd} / \mathrm{MgO}$ model catalyst, Journal of Vacuum Science \& Technology A, Vol. 6, No. 3, 1988, pp. 11131117 http://dx.doi.org/10.1116/1.575655 
[19] Xu, C. - Oh, W. S. - Liu, G. - Kim, D. Y. - Goodman, D. W. : (1997) Characterization of metal clusters ( $\mathrm{Pd}$ and $\mathrm{Au}$ ) supported on various metal oxide surfaces $\left(\mathrm{MgO}\right.$ and $\left.\mathrm{TiO}_{2}\right)$, Journal of Vacuum Science \& Technology A, Vol. 15, No. 3, 1997, pp. 1261-1268 http://dx.doi.org/10.1116/1.580604

[20] Henry, C. R. - Chapon, C. - Duriez, C. - Giorgio, S. : (1991) Growth and morphology of palladium particles epitaxially deposited on a $\mathrm{MgO}(100)$ surface, Surface Science, Vol. 253, No. 1-3, 1991, pp. 177-189 http://dx.doi.org/10.1016/0039-6028(91)90591-F

[21] Fornander, H. - Hultman, L. - Birch, J. - Sundgren, J.-E. : (1998) Initial growth of Pd on $\mathrm{MgO}(000$ 1), Journal of Crystal Growth, Vol. 186, No. 1-2, pp. 189-202 http://dx.doi.org/10.1016/S0022-0248(97)00443-0

[22] Goyhenex, C. - Meunier, M. - Henry, C. R.: (1996) Limitation of Auger electron spectroscopy in the determination of the metal-on-oxide growth mode: Pd on MgO(100), Surface Science, Vol. 350, No. 1-3, 1996, pp. 103112. http://dx.doi.org/10.1016/0039-6028(95)01255-9

[23] Xu, Lijun - Campbell, Charles T. - Jónsson, Hannes - Henkelmana, Graeme: (2007) Kinetic Monte Carlo simulations of Pd deposition and island growth on $\mathrm{MgO}(10$ 0), Surface Science Vol. 601, No. 14, pp. 31333142 http://dx.doi.org/10.1016/j.susc.2007.05.027

[24] Venables, J. A. - Harding, J. H. : (2000) Nucleation and growth of supported metal clusters at defect sites on oxide and halide $\left(\begin{array}{lll}0 & 0 & 1\end{array}\right)$ surfaces, Journal of Crystal Growth, Vol. 211, No. 1-4, 2000, pp. $27-33$ http://dx.doi.org/10.1016/S0022-0248(99)00837-4

[25] Henry, C. R. - Meunier, M.: (1998) Power laws in the growth kinetics of metal clusters on oxide surfaces, Vacuum, Vol. 50, No. 1-2, pp. 157-163 http://dx.doi.org/10.1016/S0042-207X(98)00034-7

[26] Giordano, Livia - Di Valentin, Cristiana - Pacchioni, Gianfranco Goniakowski, Jacek: (2005) Formation of Pd dimers at regular and defect sites of the $\mathrm{MgO}\left(\begin{array}{lll}1 & 0 & 0\end{array}\right)$ surface: cluster model calculations, Chemical Physics, Vol. 309, No. 1, 2005, pp. 41-47 http://dx.doi.org/10.1016/j.chemphys.2004.02.022

[27] Sicolo, Sabrina - Pacchioni, Gianfranco: (2008) Charging and stabilization of Pd atoms and clusters on an electron-rich $\mathrm{MgO}$ surface, Surface Science Vol. 602, No. 16, pp. 2801-2807 http://dx.doi.org/10.1016/j.susc.2008.07.005

[28] Giordano, Livia - Pacchioni, Gianfranco: (2005) Pd nanoclusters at the $\mathrm{MgO}(100)$ surface, Surface Science Vol. 575, No. 1-2, pp. 197-209 http://dx.doi.org/10.1016/j.susc.2004.11.024

[29] Renaud, Gilles: (2005) Real-Time Monitoring of Growing Nanoparticles by in situ Small Angle Grazing Incidence X-Ray Scattering, AIP Conference Proceedings, Vol. 748. No. 63, 2005 http://dx.doi.org/10.1063/1.1896476

[30] Robinson, V. N. E. - Robins, J. I.: (1974) Nucleation kinetics of gold deposited onto UHV cleaved surfaces of $\mathrm{NaCl}$ and $\mathrm{KBr}$, Thin Solid Films, Vol. 20, No. 1, pp. 155-175 http://dx.doi.org/10.1016/0040-6090(74)90043-1

[31] Kashchiev, D.: (1976) Kinetics of thin film coalescence due to crystallite surface migration, Surface Science Vol. 55, No. 2, pp. 477-493 http://dx.doi.org/10.1016/0039-6028(76)90253-3

[32] Zinsmeister, G.: (1966) A contribution to Frenkel's theory of condensation, Vacuum, Vol. 16, No. 10, pp. 529-535 http://dx.doi.org/10.1016/0042-207X(66)90349-6

[33] Volmer, M.: Kinetic der Phasenbildung. T. Steinkopff Verlag, Leipzig (1939)

[34] Halpern, V.: (1969) Cluster Growth and Saturation Island Densities in Thin-Film Growth, Journal of Applied Physics, Vol. 40, No. 11, 1969, pp. 4627-4636 http://dx.doi.org/10.1063/1.1657243

[35] Sigsbee, R.: (1971) Adatom Capture and Growth Rates of Nuclei, Journal of Applied Physics, Vol. 42, No. 10, 1971, pp. 3904-3915 http://dx.doi.org/10.1063/1.1659705

[36] Stowell, M. J.: (1972) Capture numbers in thin film nucleation theories, Philosophical Magazine, Vol. 26, No. 2, 1972, pp. 349-360 http://dx.doi. org/10.1080/14786437208227433

[37] Lewis, B.: (1970) Migration and capture processes in heterogeneous nucleation and growth: I. Theory, Surface Science, Vol. 21, No. 2, pp. 273-288 http://dx.doi.org/10.1016/0039-6028(70)90234-7

[38] Venables, J. A.: (1973) Rate equation approaches to thin film nucleation kinetics, Philosophical Magazine, Vol. 27, No. 3, 1973, pp. 697-738 http://dx.doi.org/10.1080/14786437308219242
[39] Lewis, B. - Rees, G. J.: (1974) Adatom migration, capture and decay among competing nuclei on a substrate, Philosophical Magazine, Vol. 29, No. 6, 1974, pp. 1253-1280 http://dx.doi.org/10.1080/14786437408226184

[40] Venables, J. A.: (1994) Atomic processes in crystal growth, Surface Science, Vol. 299-300, No. 2, 1994, pp. 798-817 http://dx.doi.org/10.1016/0039-6028(94)90698-X

[41] Nichols, F. A. - Mullins, W. W.: (1965) Morphological Changes of a Surface of Revolution due to Capillarity-Induced Surface Diffusion, Journal of Applied Physics, Vol. 36, No. 6, 1965, pp. 1826-1835 http://dx.doi.org/10.1063/1.1714360

[42] Menck, A.: Ph.D. thesis, Lausanne, 1998

[43] Højrup-Hansen, K. - Ferrero, S. - Henry, C. R.: (2004) Nucleation and growth kinetics of gold nanoparticles on $\mathrm{MgO}\left(\begin{array}{lll}1 & 0 & 0\end{array}\right)$ studied by UHVAFM, Applied Surface Science, Vol. 226, No. 1-3, pp. 167-172 http://dx.doi.org/10.1016/j.apsusc.2003.11.017

[44] Meunier, M.: Ph.D. thesis, Marseille, 1995

[45] C.R. Henry (1998) Surface studies of supported model catalysts, Surface Science Reports, Vol. 31, No. 7-8, pp. 231-325 http://dx.doi.org/10.1016/S0167-5729(98)00002-8

[46] Carrey, J. - Maurice, J.-L. - Petro, F. - Vaurès, A. : (2002) Growth of Au clusters on amorphous $\mathrm{Al}_{2} \mathrm{O}_{3}$ : are small clusters more mobile than atoms?, Surface Science, Vol. 504, 2002, pp. 75-82 http://dx.doi.org/10.1016/ S0039-6028(01)01796-4

[47] Carrey, J. - Maurice, J.-L.: (2002) Scaling laws near percolation during three-dimensional cluster growth: A Monte Carlo study, Physical Review B, Vol. 65, No. 20, 2002, 205401 http://dx.doi.org/10.1103/PhysRevB.65.205401

[48] Bartelt, M. C. - Evans, J. W.: (1994) Dendritic islands in metal-on-metal epitaxy I. Shape transitions and diffusion at island edges, Surface Science, Vol. 314, No. 1, 1994, pp. L829-L834 http://dx.doi.org/10.1016/S0039-6028(01)01796-4

[49] Harsdorff, M.: (1982) Heterogeneous nucleation and growth of thin films, Thin Solid Films, Vol. 90, No. 1, pp. 1-14 http://dx.doi.org/10.1016/0040-6090(82)90061-X

Ref.:

Baara, F. - Chemam, A.: Formation of Catalyst Model Dispersed of Pd on a thin $\mathrm{MgO}$ (100)

Építőanyag - Journal of Silicate Based and Composite Materials, Vol. 66, No. 4 (2014), 100-104. p. http://dx.doi.org/10.14382/epitoanyag-jsbcm.2014.18

\section{Pd diszperz katalizátor modell képződése a vékony MgO (100) rétegen}

A szerzốk a Fortran szofter felhasználásával egy szimulációs katalizátor modellt dolgoztak ki a diszpergált Pd palládium nanoszemcsék alkalmazásával vékony MgO magnézium-oxid rétegen. Eza szimulációs modell a transzmissziós elektronmikroszkóppal (TEM) in-situ végzett csiraképzôdési és növekedési vizsgálati adatokon alapszik Az elsố kvantitatív vizsgálat a nucleation és a növekedést. A palládium nanorészecskék beépülését a vékony MgO rétegbe az 573-1073 K-fok hômérséklet-tartományban tesztelték 1000 sec hôkezelési idôtartam alatt. Azt tapasztalták, hogy a folyamat az alábbi három szakaszra osztható: a véletlenszerūen (random) csiraképzốdés; a növekedés; és végül az egyesülés. Az Arrhenius törvénynek megfelelôen a létrejött klaszterek telítettségi sưrūsége csökken a szubsztrátum hômérsékletének növekedésével - hasonlóan mint ahogyan ezt megfigyelték az Ag/MgO illetve Au/MgO AFM (atomic force Microscopy) tanulmányozásakor. Az egyesülési jelenség az úgynevezett sziget-migrációs folyamattal magyarázható; mely folyamat annál gyorsabb, minél magasabb a hômérséklet.

Kulcsszavak: katalizátorok, kristályok, magnézium-oxid, csiraképződés, palládium 